\title{
Activity of Two Photosensitizer Compounds for Sustainable Control of the Egyptian Cotton Leafworm, Spodoptera littoralis (Boisd.) (Lepidoptera: Noctuidae)
}

\author{
Mona Awad \\ Department of Economic Entomology and Pesticides, Faculty of Agriculture, \\ Cairo University, 12613 Giza, Egypt
}

\begin{abstract}
Activity of two photosensitizer compounds were studied on different stages of Spodoptera littoralis under laboratory conditions. Copper chlorophylline and magnesium chlorophylline as a photosensitizer compounds with different concentrations were tested on $S$. littoralis immature stages, egg, larvae and pupae. Data showed that copper chlorophylline has a slight effect while magnesium chlorophylline has no effect on egg stage of $S$. littoralis. The copper chlorophylline was more toxic on $2^{\text {nd }}$ and $4^{\text {th }}$ instar larvae than magnesium chlorophylline under both dark and photo conditions. Therefore, both compounds were more toxic under sunlight than dark conditions when pupae were immersed at different concentrations of the both photosensitizers' compounds. These results reflected that photosensitizers could be a potentially effective for S. littoralis control in Egypt.
\end{abstract}

Key words: Photosensitizer; Sustainable Control; Cotton Leafworm; Spodoptera littoralis

\section{INTRODUCTION}

The Egyptian cotton leafworm, Spodoptera littoralis (Boisd.) (Lepidoptera: Noctuidae) is considered as a serious agricultural pests that can attack important crops and causes considerable damage throughout the year in Africa, Asia and Europe (Pineda et al. 2007; Shairra and Nouh, 2014). In addition to the cotton, the $S$. littoralis larvae attack a critical plant species belonging to 40 families causing considerable losses of the infested crops. The spacious application of commercial insecticides to control this pest led to development of resistance to this chemical insecticides (Ishaaya et al., 1995). Furthermore, Chemical insecticides frequently show distasteful side effects. For instance, notable toxicity has been noticed in nontarget organism's e.g. beneficial insects, fish, or mammals. Chemical insecticides also affect human health, as their toxic residues can remain in drinking water and be accumulated in the food cycle. At the present time, there is a need for novel environmental friendly control strategies to suppress S. littoralis population.

As a result of an increasing world population, a $70 \%$ expand in global food production is needed, requiring sustainable intensification of agricultural production. One of a promising unconventional insecticides is using the photoactive substances for controlling insect pests (Filiberti et al., 2009; Dondji et al., 2005). These substances are known as Photosensitizers which are converted into a toxic photoproducts (Spikes, 1986). Photosensitization includes activation of light-sensitive compounds, which producing chemical reactions that cause damage or demolish for the cells. The photosensitizing catalyst by sunlight or artificial light sources irradiation (Ben Amor et al. 2000) have been shown to be cumulatively in remarkable significant amounts by a diversity of insects when they are administered in association with suitable baits. The aim of this study was to evaluate the efficiency of photosensitizers including; Copper chlorophylline and Magnesium chlorophylline as photoinsecticides were applied on the different immature stages of $S$. littoralis to determine their effectiveness for $S$. littoralis management.

\section{MATERIALS AND METHODS}

\section{Insect culture}

Laboratory strain of $S$. littoralis used in this study has been reared in the laboratory in the absence to any insecticides as described by ElDefrawi et al. (1964).

Chemicals

Two photosensitizer Copper chlorophylline $(\mathrm{Cu})$ and Magnesium chlorophylline $(\mathrm{Mg})$ were taken out from laboratory of stored product insects, Department of Economic Entomology and Pesticides, Faculty of Agriculture Cairo University.

Bioassays of Photosensitizer in S. littoralis stages Toxic effect on egg stage

Toxicity of the two photosensitizer (Copper chlorophylline and Magnesium chlorophylline) under dark and photo conditions were tested on two egg masses of different ages ( 24 and $48 \mathrm{~h}$ old). Stock solution $(1 \mathrm{mg} / \mathrm{L})$ of each testing compounds was diluted with water to get a serial concentrations of $0.01,0.001,0.0001$ and $0.00001 \mathrm{mg} / \mathrm{L}(\mathrm{ppm})$. Small pieces of egg batches papers were cut and dipped for 5 second in each concentration. The treated and untreated (which dipped in only water) 
eggs were taken to a clean petri-dish after drying and kept at $25 \pm 1{ }^{\circ} \mathrm{C}, 70 \pm 5 \% \mathrm{RH}$. The mortality of treated eggs was calculated daily till 5 days posttreatment.

\section{Lethal effect on larval stage}

Susceptibility of $2^{\text {nd }}$ and $4^{\text {th }}$ instar larvae of $S$. littoral to Copper chlorophylline and Magnesium chlorophylline under dark and photo conditions were investigated by using the leaf dipping technique. Four different concentrations from each compound; 0.01, 0.001, 0.0001 and $0.00001 \mathrm{mg} / \mathrm{L}$ (ppm) were prepared. The castor bean leaves were immersed in each concentration for 20 second, while control leaves were treated with Tab water. After drying, a pair of leaves was placed into a glass jar (0.5 L) with larvae (Hamada et al., 2018). Four replicates (25 larvae/ replicate) for each concentration were allowed to feed on treating leaves for $24 \mathrm{hrs}$. Then, the larvae were transferred to a clean glass jar to fed on untreated leaves. Mortality percentage was recorded after 4 days after treatments ( $96 \mathrm{hrs}$ post-treatment).

\section{Activity on pupal stage}

The serial concentrations of both photosensitizer, which described above were used to test their activity on the pupae ( $24 \mathrm{~h}$ old) of $S$. littoralis. Three replicates (10 pupae/ replicate) were used. Mortality of pupae and adult emergence were taken and recorded daily till a period of 10 days. Statistical Analysis

Data were analyzed with the aid of the regression analysis and one way ANOVA (the d.f., $\mathrm{F}$ and P-values were established) included in the Graph Pad Prism 4 software (Graph- Pad Software Inc., La Jolla, CA).

\section{RESULTS}

Ovicidal activity of Photosensitizer compounds

Effect of photosensitizer compounds on two different egg ages of $S$. littoralis, under sunlight and dark conditions, was presented in Figure 1 and 2. The results showed that the mortality was about $32 \%$ and $32 \%$ in eggs ( $24 \mathrm{~h}$ old) that were treated with the copper chlorophylline $(\mathrm{Cu})$ at $0.01 \mathrm{mg} / \mathrm{L}$ under sunlight and dark conditions, respectively. While, the mortality was $23 \%$ and $25 \%$ in eggs (48 $\mathrm{h}$ old). In contrast, there was no effect on both egg masses' ages after treated with magnesium chlorophylline $(\mathrm{Mg})$, data doesn't shown.

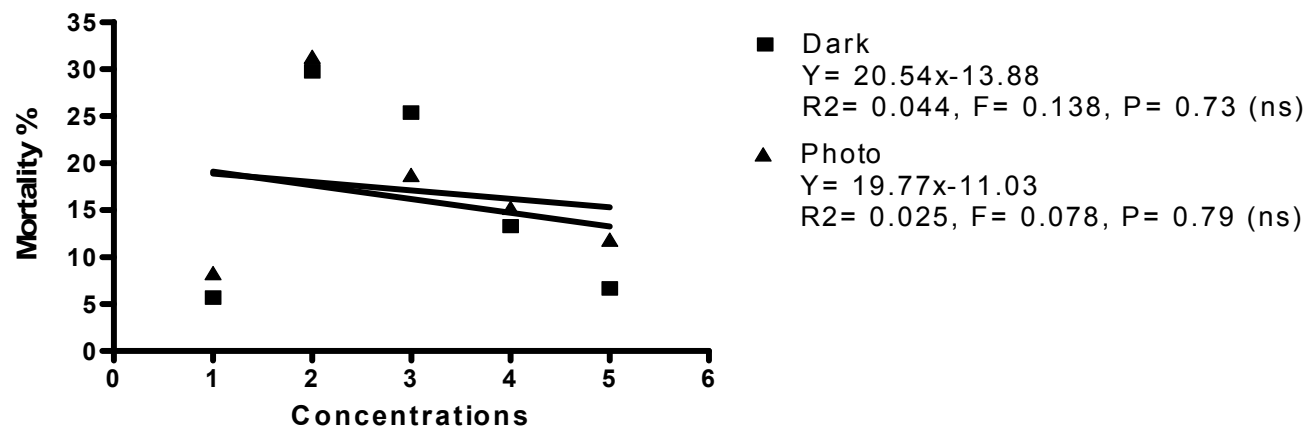

Fig. 1: Effect of different concentrations $(1=\operatorname{control}, 2=0.01,3=0.001,4=0.0001$, and $5=0.00001 \mathrm{mg} / \mathrm{L}) \mathrm{of}$ photosensitizer $(\mathrm{Cu})$ on egg masses $(24 \mathrm{~h}$ old $)$ of $S$. littoralis.

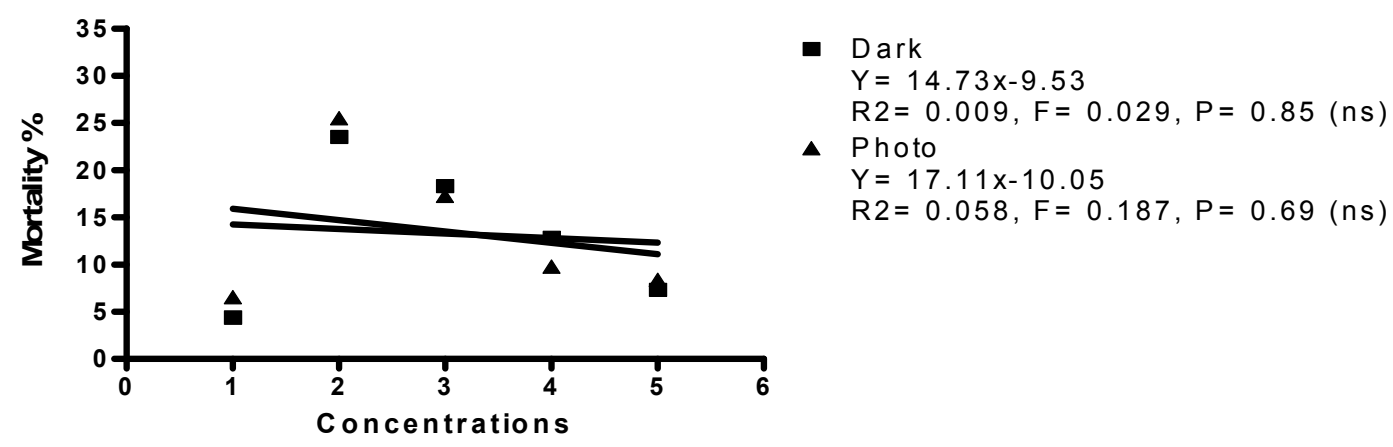

Fig. 2:

Fig. 2: Effect of different concentrations $(1=$ control, $2=0.01,3=0.001,4=0.0001$, and $5=0.00001 \mathrm{mg} / \mathrm{L}) \mathrm{of}$ photosensitizer $(\mathrm{Cu})$ on egg masses $(48 \mathrm{~h}$ old $)$ of $S$. littoralis. 
Toxicity on $2^{\text {nd }}$ and $4^{\text {th }}$ larval instars to photosensitizer compounds

Toxicity of copper chlorophylline and magnesium chlorophylline on $2^{\text {nd }}$ and $4^{\text {th }}$ instar larvae of $S$. littoralis under dark and photo conditions was presented in Figures 3 and 4 . The rat of mortality after treated $2^{\text {nd }}$ and $4^{\text {th }}$ instar larvae with $0.1 \mathrm{mg} / \mathrm{L}$ of copper chlorophylline was $29.5 \%$ and $76 \%$, respectively, under dark condition (Figure 3) and was $38.9 \%$ and $96 \%$, respectively, under photo condition (Figure 3 ). In contrast, the mortality ratio after treated the larvae with magnesium chlorophylline was $49.5 \%$ and $54.9 \%$, respectively, under dark condition (Figure 4 ) and was $59.1 \%$ and $52 \%$, respectively, under photo condition (Figure 4).

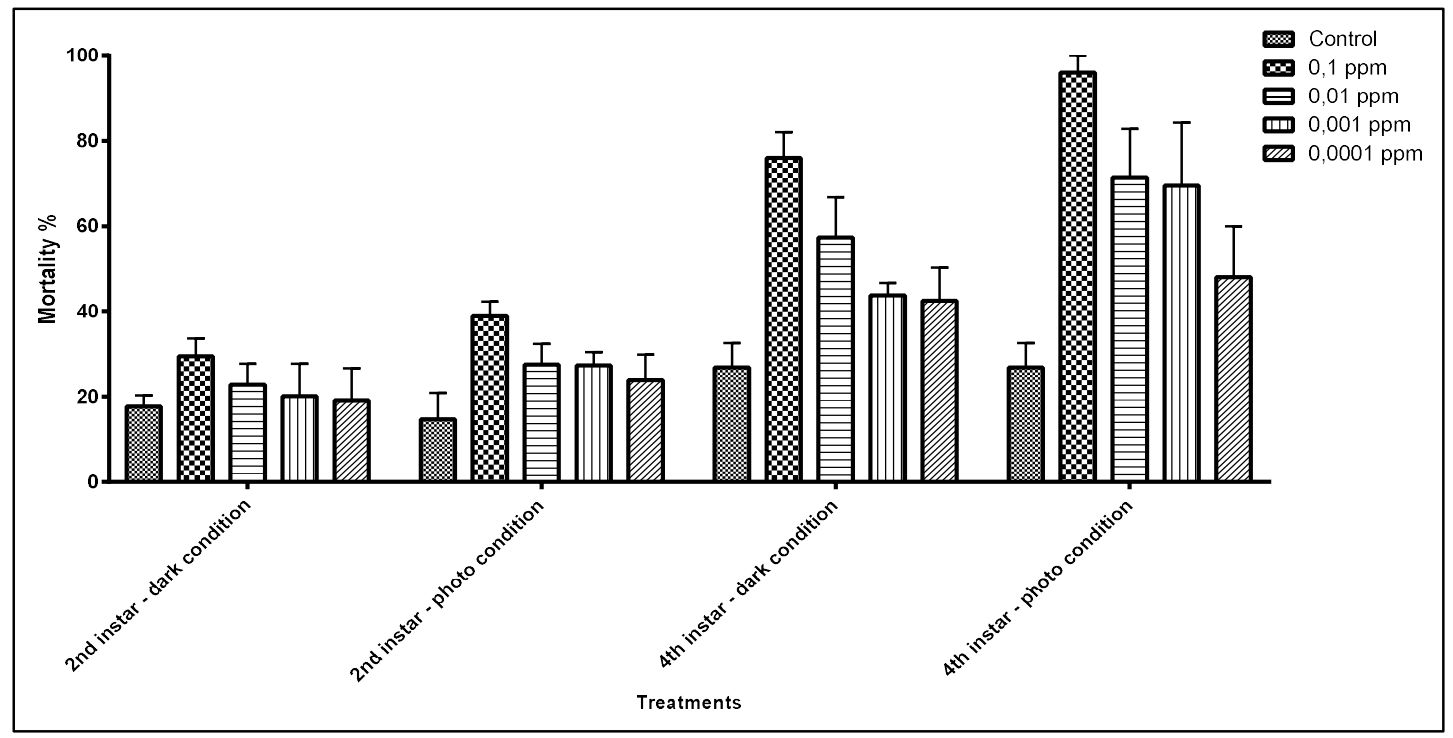

Fig. 3: Effect of photosensitizer $(\mathrm{Cu})$ on $2^{\text {nd }}$ and $4^{\text {th }}$ instars of $S$. littoralis larvae after 4 days post treatment under dark and photo conditions.

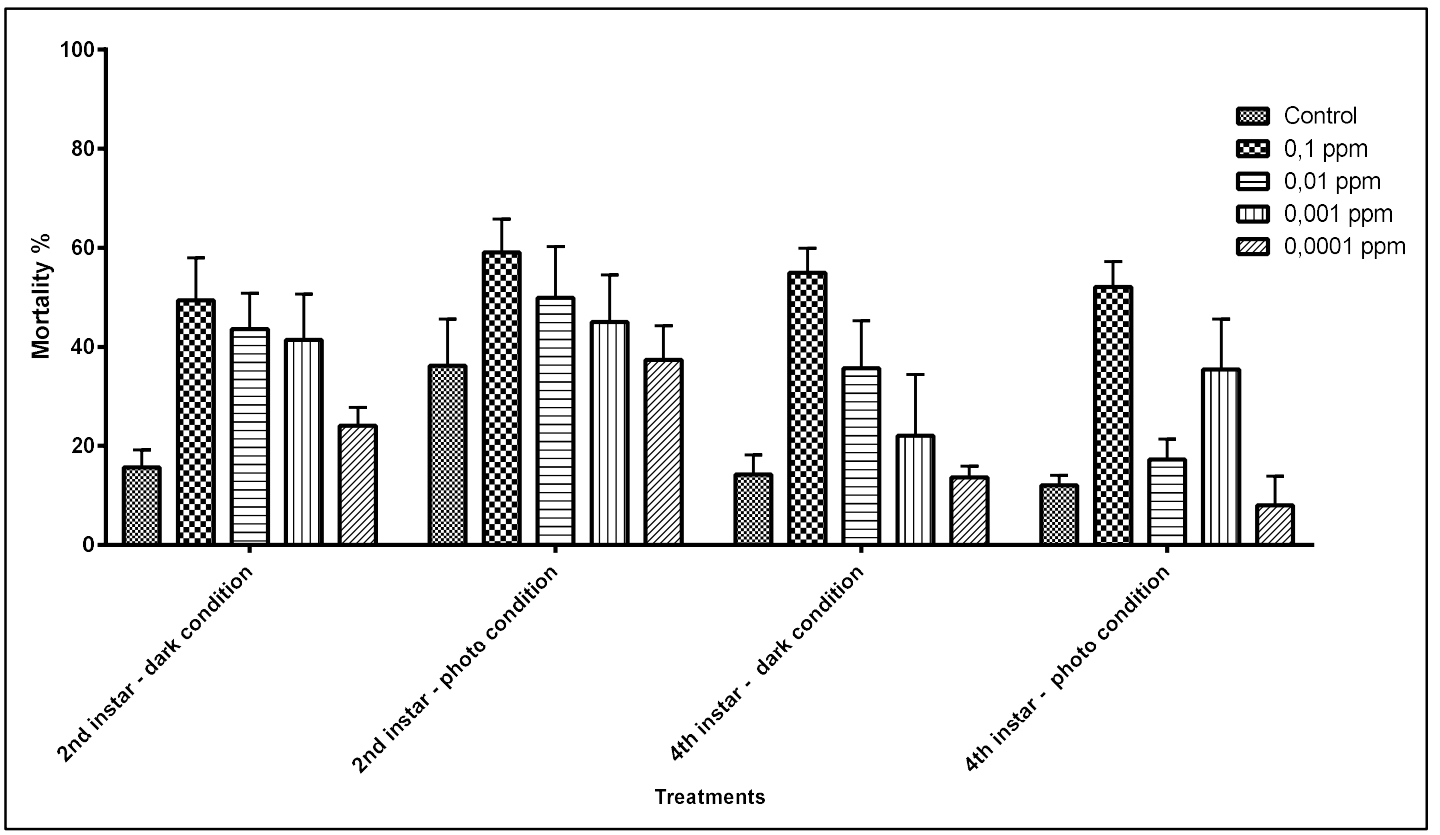

Fig. 4: Effect of photosensitizer $(\mathrm{Mg})$ on $2^{\text {nd }}$ and $4^{\text {th }}$ instars of $S$. littoralis larvae after 4 days post treatment under dark and photo conditions. 
Effect of photosensitizer compounds on pupal stage

Result showed that both photosensitizer compounds including; copper chlorophylline $(\mathrm{Cu})$ and magnesium chlorophylline $(\mathrm{Mg})$ at sunlight condition, were more influential than at dark conditions, after treated pupal stage of $S$. littoralis with different concentrations of those compounds (Figures 11 and 12). In contrast, copper chlorophylline $(\mathrm{Cu})$ was more influential than magnesium chlorophylline $(\mathrm{Mg})$ after treated the pupae in both dark and sunlight conditions with mortality of $58 \%$ and $85 \%$ in case of $\mathrm{Cu}$ and $43 \%$ and $35 \%$ in case of $\mathrm{Mg}$ at $0.01 \mathrm{mg} / \mathrm{L}$, respectively. Pupal mortality of the control was below $10 \%$.

\section{DISCUSSION}

In Egypt, Agriculture is one of the important section of the Egyptian economy. Safer methods are needed to conserve the economic crops from potential insect pests. The use of the photochemicals products have been examined against several species of insects under different conditions (Rebeiz et al., 1991) or field conditions (Lenke et al., 1987). The results presented in this study confirmed the efficiency of a two of photosensitizer including; copper chlorophylline $(\mathrm{Cu})$ and magnesium chlorophylline $(\mathrm{Mg})$ against immature $S$. littoralis. The results showed a slight effect of copper chlorophylline $(\mathrm{Cu})$ on egg stage while with magnesium chlorophylline $(\mathrm{Mg})$ was not. In contrast, both substances exhibited a significant impact on larval stage of $S$. littoralis.

On the flesh fly, Parasarcophaga argyrostoma, a high mortality ratio in adult flies reached to $96 \%$ has been obtained after treated to the photosensitizer (Hematoporphyrin IX) and sunlight in sugar bait traps (El-Tayeb et al., 2011). Therefore, Berni et al. (2009) tested the effect of Xanthene dyes as photoinsecticides on various species of dipteran insect pest, and they found that Phloxine B which ingested by Ceratitis capitata larvae was decreased the toxicity under dark conditions, while acute lightdependent toxicity was obtained when the insects were exposed to light during the dispersion stage before pupation. In addition, the photosensitizer of hematoporphyrin dimethyl ether caused a fast death of Liriomyza bryoniae, Diptera: Agromyzidae (Lukšiene et al., 2007).

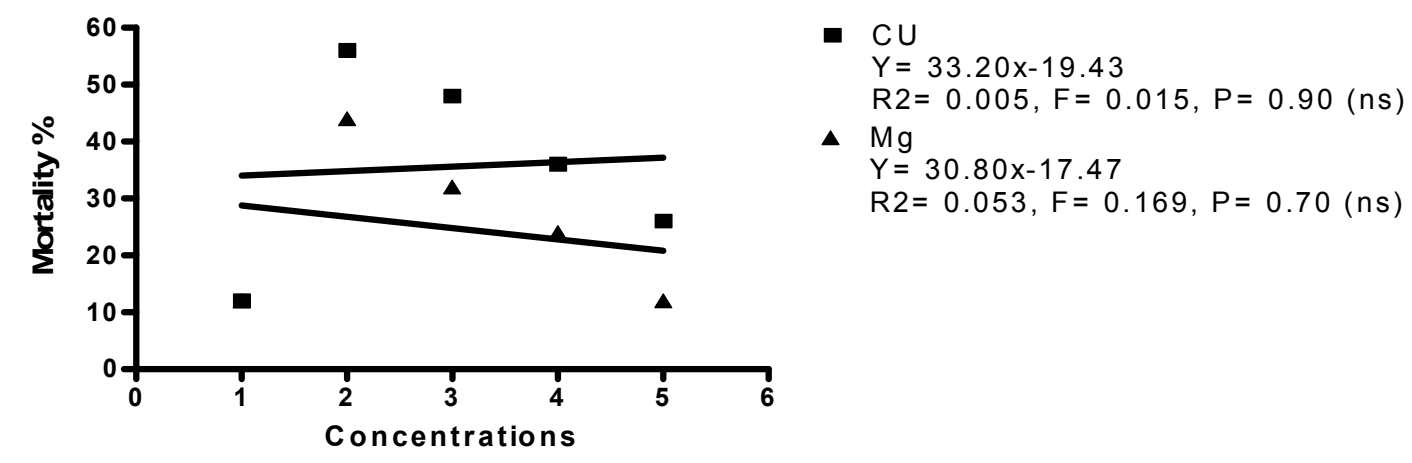

Fig. 5: Effect of different concentrations $(1=$ control, $2=0.01,3=0.001,4=0.0001$, and $5=0.00001 \mathrm{mg} / \mathrm{L}) \mathrm{of}$ photosensitizer ( $\mathrm{Cu} \& \mathrm{Mg}$ ) on pupal stage of $S$. littoralis under dark condition.

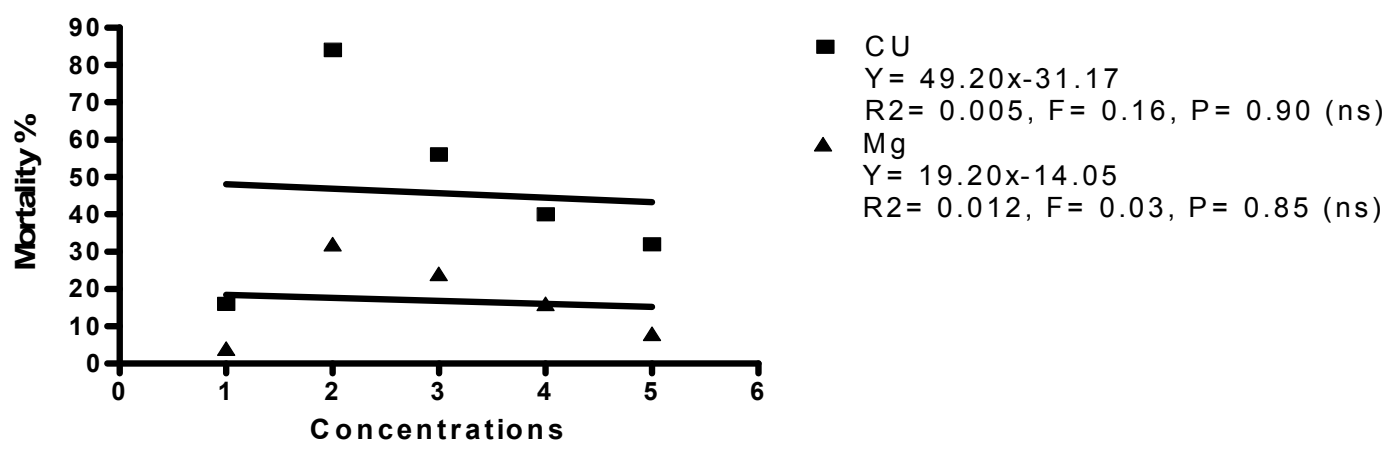

Fig. 6: Effect of different concentrations $(1=\operatorname{control}, 2=0.01,3=0.001,4=0.0001$, and $5=0.00001 \mathrm{mg} / \mathrm{L}) \mathrm{of}$ photosensitizer ( $\mathrm{Cu} \& \mathrm{Mg}$ ) on pupal stage of $S$. littoralis under photo condition. 
Moreover, the photosensitizers exhibited lethal effects against fourth instar larvae and adults of mosquitoes under laboratory and field conditions (Helleck and Hartberg, 2000; Dondji et al., 2005).

The obtained data suggested that suppressing the cotton leafworm, S. littoralis, and population using photosensitizers as photoinsecticides will participate in the protection of cultivation of several vegetables and crops which will have a great impact on the economic development of agriculture.

\section{ACKNOWLEDGMENT}

Author is appreciate Prof. Dr Sayda Said for providing the photosensitizer and Prof. Dr. Mahmoud Hashem AbdELKader for his technical support.

\section{REFERENCES}

Ben Amor, T.; L. Bortolotto and G. Jori (2000). Porphyrins and Related Compounds as Photoactivatable Insecticides. 3. Laboratory and Field Studies. Photochemistry and Photobiology, 71: 124-128.

Berni, J.A.J.; P.J. Zarco-Tejada; L Suarez and E. Fereres (2009). Thermal and narrowband multispectral remote sensing for vegetation monitoring from an unmanned aerial vehicle. IEEE T Geosci Remote, 47: 722-38.

Dondji, B.; S. Duchon; A. Diabate; J.P. Herve; V. Corbel; J-M. Hougard; R. Santus and J. Schrevel (2005). Assessment of laboratory and field assays of sunlight-induced killing of mosquito larvae by photosensitizers. Journal of Medical Entomology, 42: 652-656.

El-Defrawi, M.E.; A.T. Tappozada; A. Salama and S.A. El-Khishen (1964). Toxicological studies on the Egyptian cotton leafworm Prodenia litura F.II. Reversions of Toxaphene resistance in the Egyptian cotton leafworm. Journal of Economic Entomology, 18: 265-267.

El-Tayeb, T.; M. Gharib and A. Al-Gendy (2011). Prelimi nary study to investigate the optimum parameters of using hematoporphyrin ix to control flesh fly (Para sarcophaga argyrostoma). Journal of Entomology, 8: 38439.

Filiberi. A; A. Rabossi; C.E. Argaraña and L. A. Quesada - Allué (2009). Evaluation of phloxine B as a photoinsecticide on immature stages of the horn fly, Haematobia irritans (L.) (Diptera: Muscidae). Australian Journal of Entomology, 48: 73-78.
Hamada, H.M.; M. Awad; M. EL-Hefny and M.A.M. Moustafa (2018). Insecticidal activity of garlic (Allium sativum) and ginger (Zingiber officinale) oils on the cotton leafworm, Spodoptera littoralis (Boisd.) (Lepidoptera: Noctuidae). African Entomology, 26: 84-94.

Helleck, A.M. and W.K. Hartberg (2000). Effects of Photofrin II on Adults of Eretmapodites quinquevittatus. Journal of the American Mosquito Control Association, 16: 248-253.

Ishaaya, I.; S. Yablonski and A.R. Horowitz (1995). Comparative toxicity of two ecdysteroid agonists, RH-2485 and RH-5992, on susceptible and pyriproxyfen-resistant strains of the Egyptian cotton leafworm, Spodoptera littoralis. Phytoparasitica, 23:139-45.

Lenke, L.A.; P.G. Koehler; R.S. Patterson; M.B. Feger and A. Eickhoff (1987). Field development of photooxidative dyes as insecticides. In: Heitz, J.R., Downum, K.R. (Eds.), Light Activated Pesticides. ACS, Washington DC, pp. 156-167.

Lukšiene, Z.; H. Danilcenko; Z. Taraseviciene; Z. Anusevicius; A. Maroziene and H. Nivinskas (2007). New approach to the decontamination of germinated wheat from microfungi: effects of aminolevulinic acid. International Journal of Food Microbiology, 116: 153-158.

Pineda, S.; M.A. Schneider; G. Smagghe; A.M. Martinez; P.D. Estal; E. Vinuela; J. Valle and F. Budia (2007). Lethal and sublethal effects of methoxyfenozide and spinosad on Spodopera littoralis (Lepidoptera: Noctuidae). Journal of Economic Entomology, 103: 662-667.

Shairra, S.A and G.M. Nouh (2014). Efficacy of entomopathogenic nematodes and fungi as biological control agents against the cotton leaf worm, Spodoptera littoralis (Boisd.) (Lepidoptera: Noctuidae). Egyptian Journal of Biological Pest Control, 24: 247-253.

Spikes J.D. (1986). Phthalocyanines as photosensitizers in biological system and for the photodynamic therapy of tumors. Phofochetnistry and Photobiology, 43: 691699.

Rebeiz, C.A.; U.B. Nandihalli and K.N. Reddy (1991). Tetrapyrrole dependent photodynamic herbicides and chlorophyll biosynthesis modulators. In: Baker, N.R., Percival, M.B. (Eds.), Herbicides. Elsevier, Amsterdam, pp. 173-208. 


\section{الملخص العربي \\ نشاط اثثين من المستحثات الضوئية في المكافحة المستدامة لاودة ورق القطن

\author{
مني عوض \\ قسم الحشرات الأقتصادية و المبيدات - كلبة الزراعة - جامعة القاهرة - بابشبا جيزة - مصر
}

أجريت دراسة لنشاط أثثين من المستحثات الضوئية على الأطوار المختلفة من حشرة دودة ورق القطن Spodoptera littoralis

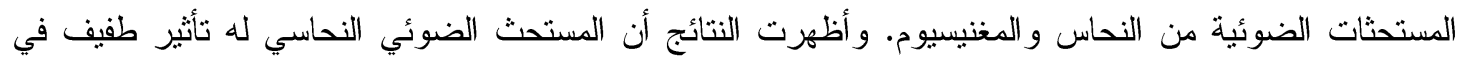
حين أن المستحث الضوئي المغنيسيومي ليس له أي تأثير على طور البيض من كان المستحث الضوئي النحاسي أكثر سمية علي يرقات الطور الثاني والرابع من المستحث الضوئي المغنيسيومي

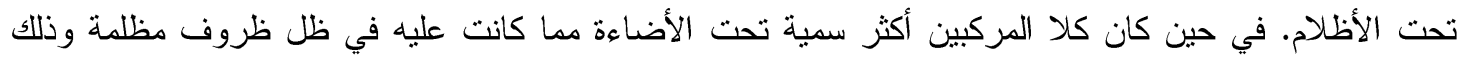
عندما تم معاملة طور العذارء في تركيزات مختلفة من كلا من المستحث الضوئي النحاسي و المغنيسيومي. الأمر فير فئه الذي يشير إلى أن المستحثات الضوئية من الممكن أستخدامها في مكافحة حشرة دودة ورق من من القطن في مصر. 